\title{
PENYEIMBANG DINAMIK DENGAN PENDEKATAN SUDUT FASA PADA SISTEM POROS ROTOR
}

\author{
Haruman Wiranegara \\ Balai Besar Logam dan Mesin (BBLM), Kementerian Perindustrian, \\ Jl. Sangkuriang No. 12 Kota Bandung, Jawa Barat. \\ Pos-el: haruman@kemenperin.go.id
}

\begin{abstract}
ABSTRAK
Penyeimbang dinamik (dynamic-balancing) telah banyak diimplementasikan pada mesin-mesin yang beroperasi pada putaran tinggi, seperti turbin gas, propeller, dan sebagainya., hal ini dilakukan karena akibat ketidaksempurnaan pada proses manufaktur menyebabkan putaran komponen menjadi tidak seimbang (unbalance) dan menimbulkan getaran yang tinggi dan resonansi pada putaran operasi, yang pada akhirnya akan mempercepat kerusakan mesin itu sendiri. Penelitian ini bermaksud mengimplementasikan penyeimbang dinamik dengan pendekatan sudut-fasa. Penelitian ini dilakukan di Laboratorium Perancangan Mesin ITB. Metode penelitian yang dilakukan melalui dua tahap, pertama memformulasikan persamaan sudut-fasa, dan kedua pengujian metode dengan menggunakan poros-rotor peraga. Hasil pengujian menunjukan metode sudut fasa cukup efektif untuk Penyeimbang dinamik pada sistim poros-rotor.
\end{abstract}

Kata Kunci: sudut fasa, Penyeimbang dinamik, poros rotor

ABSTRACT

Dynamic-balancing has been widely implemented on machines operating at high speed, such as gas turbines, propellers, etc., This is done as a result of imperfections in the manufacturing process causes the rotation component becomes unbalanced and cause high vibration and resonance, which in turn will accelerate the damage to the machine itself. This study intends to implement dynamic-balancing with angle-phase approach. This research was conducted at the Engineering Design laboratory ITB. Methods of research conducted through two stages, the first to formulate the equation angle-phase, and the second testing method using the shaft-rotor display. The test results showed the method is quite effective for the phase angle of the dynamic-balancing the rotor-shaft system.

Keywords: phase angle, Dynamic-balancing, rotor shaft

\section{PENDAHULUAN}

Komponen-komponen mesin yang berputar yang digunakan dalam industri proses pada umumnya memiliki kecepatan putar yang tinggi, daya yang besar, dan waktu operasi yang lama, namun seringkali terjadi unbalance sebagai akibat proses pembuatan yang tidak sempurna (Indrajana, 1993). Oleh karena itu sebelum beroperasi mesin-mesin tersebut harus melalui proses balancing supaya mesin dapat berputar dengan cepat tanpa mengalami getaran dan resonansi yang tinggi (Nasution,1999)

Metode Penyeimbang dinamik saat ini telah menjadi perhatian para peneliti, salah satu pendekatan paling sering ditemukan adalah dengan menggunakan metode tiga massa coba (Nasution,1999). Walaupun demikian pendekatan baru dalam balancing masih perlu dikaji lebih banyak. Salah satu yang dapat dikembangkan adalah pendekatan sudut fasa.
Penelitian ini bermaksud mengimplementasikan Penyeimbang dinamik dengan pendekatan sudut-fasa.

\section{METODE DAN LANGKAH-LANGKAH PENELITIAN}

Penelitian ini dilakukan dengan langkahlangkah sebagai berikut :

1. Merancang poros-rotor peraga, yang dilengkapi dengan perangkat interface SCXI, vibrometer, Labview, dan MathLab,

2. Memformulasikan persamaan sudut-fasa

3. Memvalidasi poros-rotor peraga dengan pendekatan Finite Elemen (FEM) berbantuan aplikasi Mechanical Desktop dan NASTRAN 4D.

4. Pengujian metode sudut-fasa yang di implementasikan pada poros-rotor peraga

5. Menganalisis hasil Pengujian secara empirik. 


\section{METODE SUDUT FASA}

Pendekatan static dan Penyeimbang dinamik saat ini menggunakan metode tiga massa coba (Fair, 2001) Namun pendekatan lain dapat dilakukan dengan mengunakan pendekatan sudut fasa. pendekatan sudut fasa diaplikasikan pada sebuah rotor-peraga, menggunakan pendekatan dua bidang penyeimbang (datum), yang diletakkan pada posisi tertentu, bidang-bidang tersebut dinamai bidang ukur kiri $\left(A_{0}\right)$ dan bidang ukur kanan $\left(B_{0}\right)$, sedangkan sudut-fasa dinamai sudut fasa kiri $\left(\alpha_{0}\right)$ dan sudut fasa kanan $\left(\beta_{0}\right)$. Dengan prosedur sebagai berikut: (1) Rotor diputar pada kecepatan putar $\mathrm{x} \mathrm{Hz}$ untuk diukur getarannya pada bidang ukur kiri $\left(A_{0}\right)$ dan kanan $\left(B_{0}\right)$ diukur sudut fasanya pada bidang penyeimbang kiri $\left(\alpha_{0}\right)$ dan kanan $\left(\beta_{0}\right)$ dengan menggunakan bantuan sensor getaran. (2) Massa coba sebesar $M_{c}$ gram dipasang pada bidang penyeimbang kiri pada sembarang posisi. Rotor diputar pada kecepatan $\mathrm{x} \mathrm{Hz}$ untuk diukur getarannya pada bidang ukur kiri $\left(A_{1}\right)$ dan kanan $\left(B_{1}\right)$, diukur sudut fasanya pada bidang penyeimbang kiri $\left(\alpha_{1}\right)$ dan kanan $\left(\beta_{1}\right)$. (2) massa coba dipindahkan ke bidang penyeimbang kanan pada sembarang posisi. Rotor diputar pada kecepatan putar $\mathrm{x} \mathrm{Hz}$ untuk diukur getarannya pada bidang ukur kiri $\left(A_{2}\right)$ dan kanan $\left(B_{2}\right)$, diukur sudut fasanya pada bidang penyeimbang kiri $\left(\alpha_{2}\right)$ dan kanan $\left(\beta_{2}\right)$. Besar massa penyeimbang pada bidang penyeimbang pada bidang penyeimbang kiri dan kanan dihitung sebagai berikut:

Untuk bidang ukur kiri :

$$
\left(\mathrm{A}-\mathrm{A}_{0}\right) \mathrm{xQ}_{1}+\left(\mathrm{A}_{2}-\mathrm{A}_{0}\right) \mathrm{xQ}_{2}=-\mathrm{A}_{0}
$$

Untuk bidang ukur kanan :

$\left(\mathrm{B}_{1}-\mathrm{B}_{0}\right) \times \mathrm{Q}_{1}+\left(\mathrm{B}_{2}-\mathrm{B}_{0}\right) \times \mathrm{Q}_{2}=-\mathrm{B}_{0}$

$\mathrm{Q}_{1}, \mathrm{Q}_{2}=$ vektor-vektor penyeimbang pada bidang ukur kiri dan kanan Harga $Q_{1}$ dan $Q_{2}$ dihitung dengan cara determinan Jacobian :

$$
\mathrm{Q}_{1}=\frac{\left|\begin{array}{cc}
-\mathrm{A}_{0} & \left(\mathrm{~A}_{2}-\mathrm{A}_{0}\right) \\
-\mathrm{B}_{0} & \left(\mathrm{~B}_{2}-\mathrm{B}_{0}\right.
\end{array}\right|}{\left|\begin{array}{cc}
\left(\mathrm{A}_{1}-\mathrm{A}_{0}\right) & \left(\mathrm{A}_{2}-\mathrm{A}_{0}\right) \\
\left(\mathrm{B}_{1}-\mathrm{B}_{0}\right) & \left(\mathrm{B}_{2}-\mathrm{B}_{0}\right)
\end{array}\right|}
$$

$$
\mathrm{Q}_{2}=\frac{\left|\begin{array}{ll}
-\mathrm{A}_{0} & \left(\mathrm{~A}_{1}-\mathrm{A}_{0}\right) \\
-\mathrm{B}_{0} & \left(\mathrm{~B}_{1}-\mathrm{B}_{0}\right)
\end{array}\right|}{\left|\begin{array}{ll}
\left(\mathrm{A}_{2}-\mathrm{A}_{0}\right) & \left(\mathrm{A}_{1}-\mathrm{A}_{0}\right) \\
\left(\mathrm{B}_{2}-\mathrm{B}_{0}\right) & \left(\mathrm{B}_{1}-\mathrm{B}_{0}\right)
\end{array}\right|}
$$

Bentuk $Q_{1}$ dan $Q_{2}$ adalah :

$$
\mathrm{Q}=\mathrm{a}+\mathrm{bi} \text { dan } \mathrm{Q}=\sqrt{\mathrm{a}^{2}+\mathrm{b}^{2}}
$$

$\&(6)$

Besar massa penyeimbang pada bidang penyeimbang kiri dan posisinya dari penempatan massa coba:

$$
\begin{aligned}
& \mathrm{M}_{1}=\frac{\mathrm{r}_{\mathrm{M}_{\mathrm{c}}}}{\mathrm{r}_{\mathrm{M}_{1}}} \mathrm{Q}_{1} \mathrm{M}_{c} \\
& \mathrm{a}_{1}>0 \Rightarrow \mathrm{a}=\arctan \frac{\mathrm{b}_{1}}{\mathrm{a}_{1}} ;-90^{\circ}<\mathrm{a}<90^{\circ} \\
& \mathrm{a}_{1}<0 \Rightarrow \mathrm{a}=\arctan \\
& \frac{b_{1}}{a_{1}}+180^{\circ} ; 90^{\circ}<a<270^{\circ}
\end{aligned}
$$

dan besar massa penyeimbang pada bidang kanan dan posisinya dari penempatan massa coba dicari dengan persamaan (1) dan (2), dengan mengganti subscript 1 menjadi 2.

\section{PERANCANGAN POROS-ROTOR PERAGA}

Tujuan pembuatan poros rotor peraga adalah untuk melakukan pengujian metode sudut-fasa. Pengujian metode ini tidak langsung diaplikasikan pada mesin sesungguhnya, namun bertujuan mensimulasikan sinyal akibat unbalance serta dapat menempatkan massa balancing secara bebas pada dua bidang yang dimaksud. Dalam perancangan poros rotor ini, salah satu proses yang ditempuh adalah mendefinisikan kebutuhan (spesifikasi desain), perangkat uji harus dapat memperagakan ketakseimbangan statik \& dinamik. Alat peraga dirancang sedemikian berbentuk poros rotor yang memiliki dua piringan tempat meletakan massa tak seimbang, memiliki dua sensor vibrometer dan pengolah data

Untuk mencapai suatu kebutuhan atau tujuan tersebut perlu diterapkan kriteria utama yang harus dipenuhi (must) dan kriteria yang diharapkan terpenuhi (want) ${ }^{[4]}$ 
Kriteria perancangan yang harus dipenuhi oleh perangkat uji adalah sebagai berikut :

- Terjadinya fluktuasi gerakan disk dan poros yang diakibatkan oleh massa unbalance sebagai akibat dari satu atau lebih posisi massa yang berbeda

- Posisi disk harus dapat digeser dalam arah harisontal, pergeseran ini harus dapat mensimulasikan perubahan karakteristik getaran sebagai akibat dari posisi massa yang berbeda.

- Sensor harus bisa dipasang pada alat peraga dengan mudah pada bagian-bagian yang diukur.

Adapun kriteria yang diharapkan terpenuhi adalah sebagai berikut:

- Perangkat peraga mampu menunjukan ciri getaran yang diakibatkan ketakseimbangan statik \& dinamik.

- Perangkat peraga memiliki ukuran yang kecil dan ringan supaya mudah dipindah.

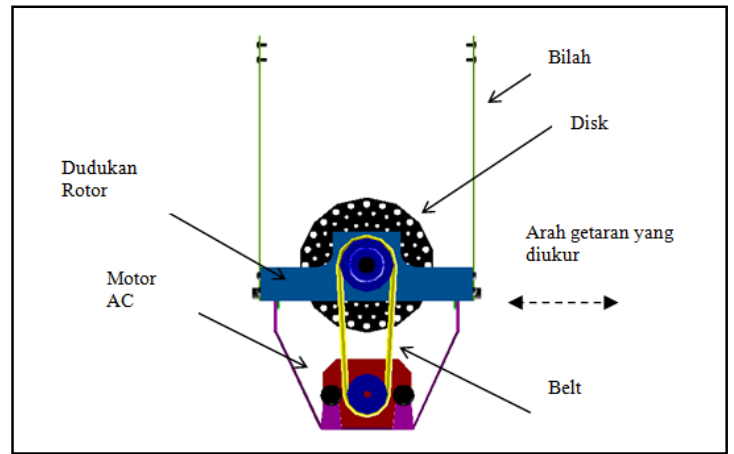

Gambar 1. Perangkat peraga pandangan samping

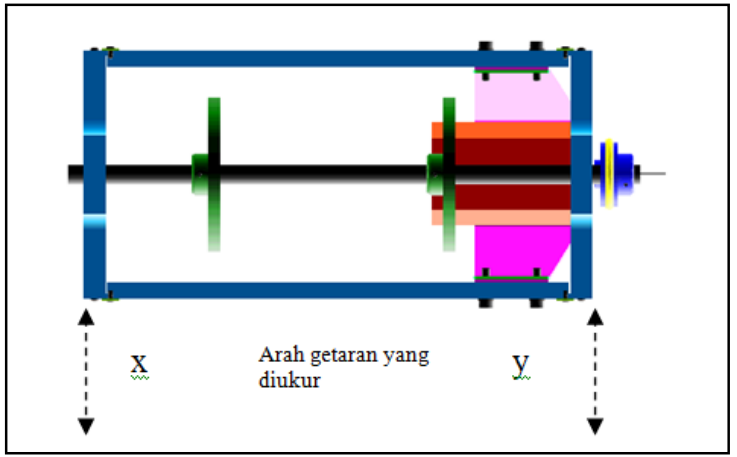

Gambar 2. Perangkat peraga pandangan atas

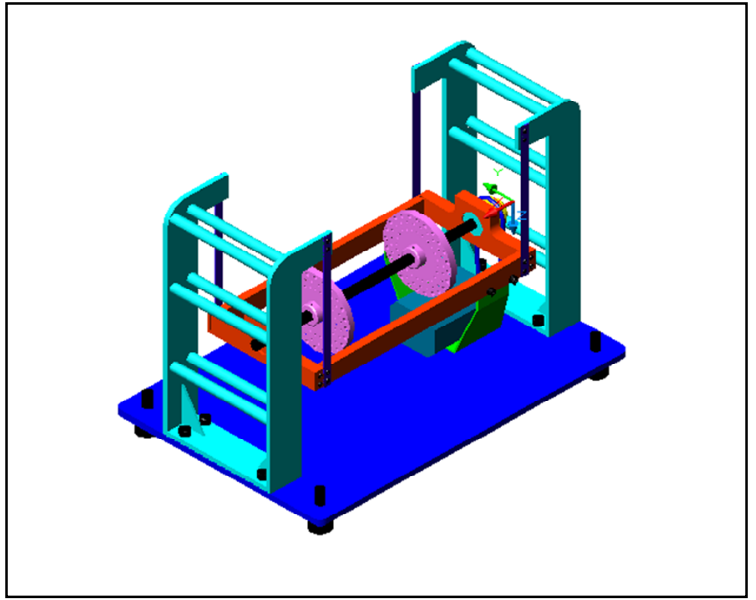

Gambar 3. Konstruksi perangkat peraga

Komponen-komponen utama dan instrumentasi pada mesin peraga ini adalah :

a. Sensor :

Sensor yang digunakan adalah proximity yang berfungsi untuk menentukan posisi disk. Proximity ini mendeteksi logam terdekat yang dipasang pada poros rotor. Untuk mendeteksi percepatan pada arah radial yang disebabkan oleh masa tak seimbang digunakan sensor accelerometer. Pada mesin ini digunakan 2 buah sensor accelerometer yang dipasang pada kedua bidang (X \& Y). Secara umum persamaan tegangan yang dikeluarkan adalah $V \approx-N \frac{\partial \phi}{\partial t}$

b. Data Akuisisi

c. Data akuisisi yang digunakan adalah LAB VIEW dengan dukungan hardware SCXI

d. Power Supply :

e. Berfungsi sebagai sumber tegangan $12 \mathrm{~V}$ DC pada sensor proximity dan accelerometer.

f. Motor \& Inverter :

g. Motor yang digunakan jenis AC 1 phase, 100 watt, $10000 \mathrm{rpm}$. Motor ini berfungsi sebagai pemutar rotor dengan menggunakan puli dan sabuk, dengan rasio putaran $1: 1,5$ (putaran rotor diperlambat kira-kira 1,5 kali). Untuk mendapatkan data pengukuran yang baik putaran motor harus dapat diatur sesuai kebutuhan. Untuk mengatur putaran motor digunakan Power Inverter. 
Instalasi alat digambarkan sebagai berikut :

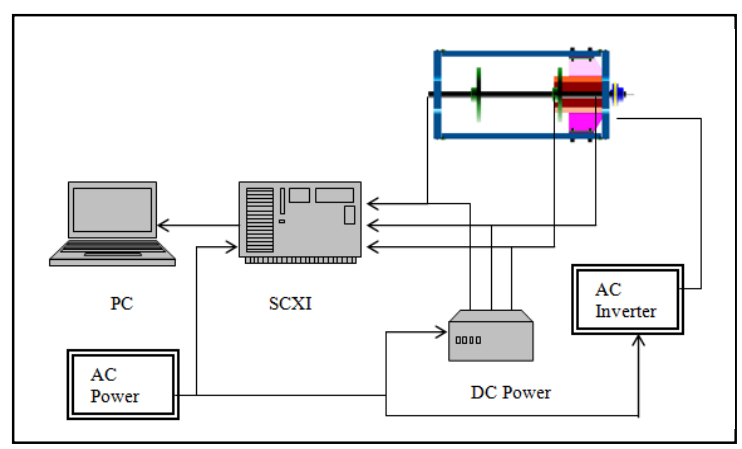

Gambar 4. Instalasi alat

\section{Aliran Pengolahan Data}

Tegangan yang keluar dari vibrometer dikonversi sebagai data akusisi melalui beberapa tahap. Pengolahan data digambarkan dalam diagram alir sebagai berikut:

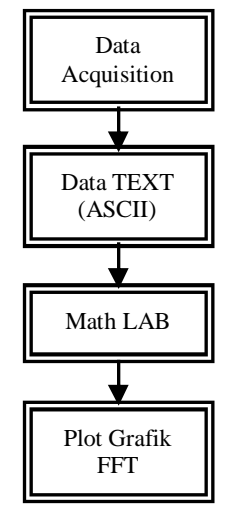

Gambar 5. Aliran Pengolahan Data

Data dari SCXI yang diterima dari sensor berupa data TEXT. Data tersebut ambil dan diolah dengan Math-LAB menjadi kurva dalam FFT (Fast Fourier Transform) (lab Dinamika, 1997)

\section{HASIL EKSPERIMEN/PENGUJIAN Deskripsi Parameter pengukuran}

Sensor getaran yang di terima SCXI yang mendeteksi adanya masa unbalance pada bidang obyek uji dengan beberapa posisi yang berbeda. Data sinyal disimpan dalam bentuk code ASCII dengan nama file uji.txt Sinyal yang diterima diolah dengan Math-LAB dan diolah berupa sinyal Fast Fourier Transform (FFT).

\section{Pengujian Tanpa Massa}

Pada pengujian ini digambarkan benda uji tanpa menggunakan beban tak seimbang, Rotor diputar pada kecepatan 1200 rpm dengan kecepatan pengambilan data 100 data perdetik. Dari pengujian ini terlihat adanya fluktuasi sinyal namun tidak diperolehnya indikasi karena adanya masa tak seimbang, fluktuasi yang ditimbulkan seperti terlihat adanya puncak-puncak amplitudo karena getaran yang ditimbulkan oleh motor listrik. Dengan melalui prosedur seperti digambarkan pada gambar 5. Diperoleh gambaran signal sebagai berikut (dalam Mathlab):

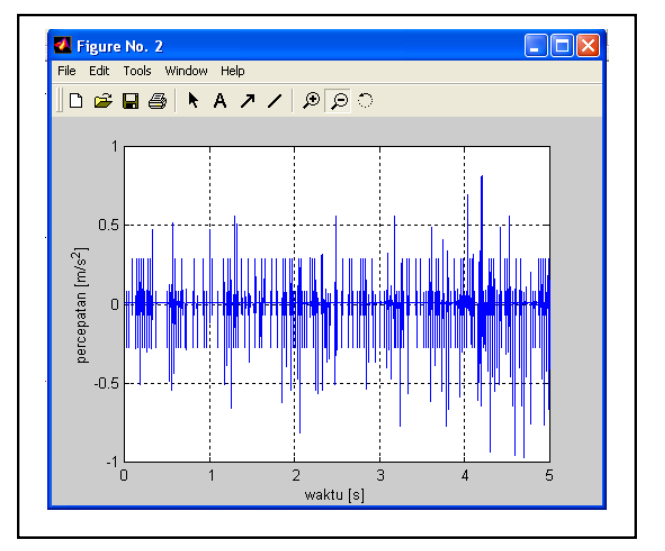

Gambar 6. Hasil pengukuran kondisi tanpa massa

Dari hasil diatas diperoleh fluktuasi berkisar antara $-0.5-0.5 \mathrm{~m} / \mathrm{s}^{2}$. Secara teoritik, kasus seperti ini diangap sebagai kondisi unbalance namun hal ini terjadi karena komponen yang tidak homogen dan unsur-unsur lain pada struktur yang menyebabkan fluktuasi terjadi

\section{Pengujian Dengan Dua Massa Beda Sudut $\mathbf{0}^{\circ}$ \\ Pada pengujian ini digambarkan benda uji} dengan menggunakan beban tak seimbang, Rotor diputar pada kecepatan $1200 \mathrm{rpm}$ (kecepatan pada inverter) dengan diberi massa tak seimbang sebesar 20,51 gram pada kedua disk dengan kecepatan pengambilan data 100 data perdetik. Dari pengujian ini terlihat diperolehnya amplitude terbesar pada frekuensi (sedikit) dibawah $20 \mathrm{~Hz}$, ini merupakan indikasi karena masa unbalance, juga terlihat adanya puncak-puncak frekwensi lain yang diindikasi karena struktur lain seperti terlihat pada gambar 8 pada $28 \mathrm{~Hz}$, diindikasi karena getaran akibat struktur lain. 


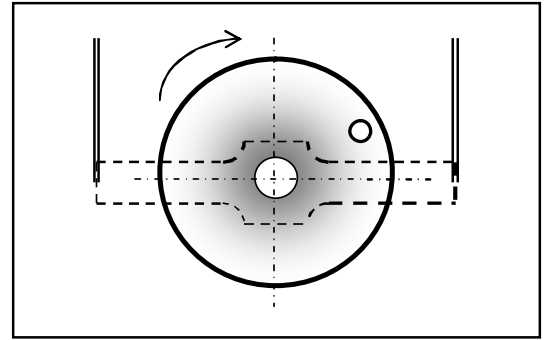

Gambar 7. Penempatan dua massa pada selisih sudut $0^{\circ}$

Hasil pengolahan data diolah dengan Aplikasi Mathlab, dengan menampilkan frekwensi. yang digambarkan sebagai berikut (hasil pengolahan Mathlab):

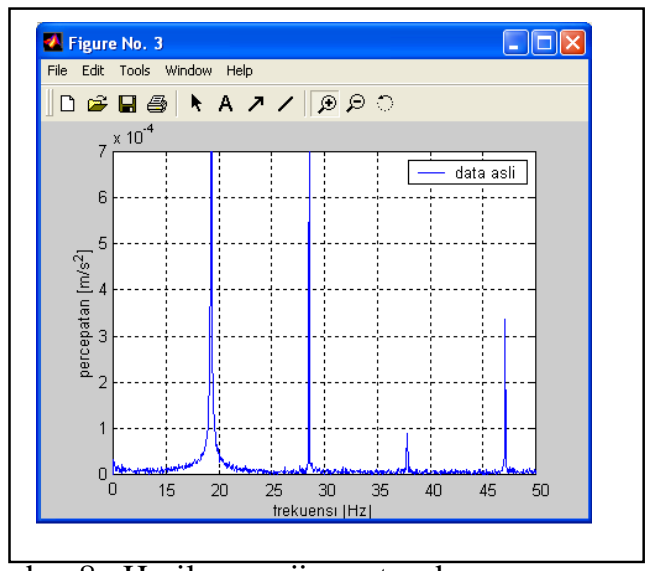

Gambar 8. Hasil pengujian rotor dengan massa unbalance model statik

\section{Pengujian Dengan Dua Massa Selisih sudut $180^{\circ}$}

Pada pengujian ini digambarkan benda uji dengan menggunakan beban unbalance, Rotor diputar pada kecepatan 1200 rpm (kecepatan pada inverter) dengan diberi massa unbalance sebesar 20,51 gram pada kedua disk dengan model dua bidang pembebenan yang berbeda dengan selisih $180^{\circ}$, sehingga minimbulkan kopel (terlihat pada gambar sketsa pemberian posisi beban ) dengan kecepatan pengambilan data 100 data perdetik.

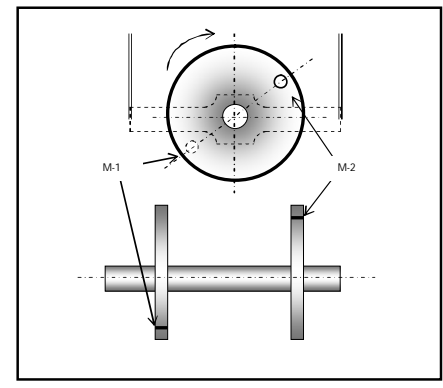

Gambar 9. Penempatan dua massa pada selisih sudut $180^{\circ}$

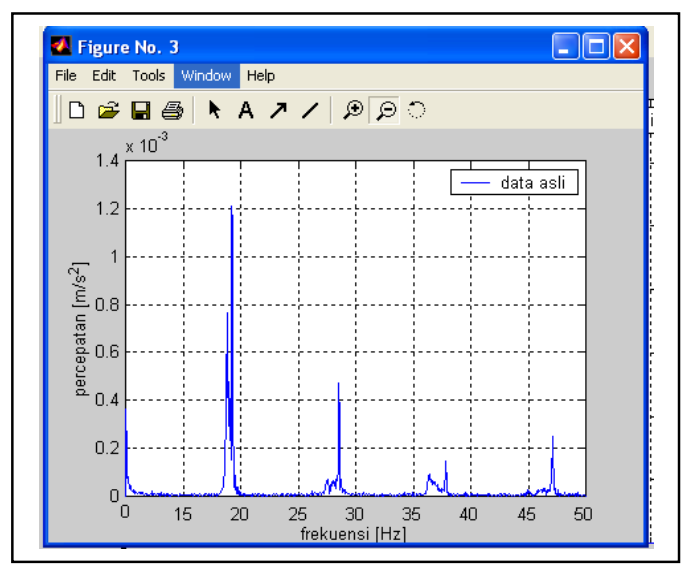

Gambar 10. Hasil pengujian rotor dengan massa unbalance model dinamik (hasil Mathlab)

Dari pengujian ini terlihat diperolehnya amplitude terbesar pada frekuensi dibawah 20 $\mathrm{Hz}$ merupakan indikasi karena masa unbalance, juga terlihat adanya puncakpuncak frekuensi lain yang diindikasi karena struktur lain seperti terihat pada gambar 10 pada $28 \mathrm{~Hz}, 37 \mathrm{~Hz}$, diindikasi karena getaran akibat struktur lain (bearing, dll).

\section{VALIDASI POROS-ROTOR PERAGA DENGAN FINITE ELEMEN CAD}

Untuk memvalidasi model poros-rotor yang dibuat, pada penelitian ini dilakukan dengan cara melakukan pemodelan dengan Mechanical Dekstop (geometriknya) kemudian analisis dilakukan diVisual NASTRAN 4D 2003 (analisisnya) (Msc Nastran, 2005) Dengan pendekatan FEM, software ini dapat merepresentasikan simulasi gerakan, kecepatan, percepatan, tegangan, gaya pada titik pool, dll. Adapun pemodelan adalah sebagai berikut :

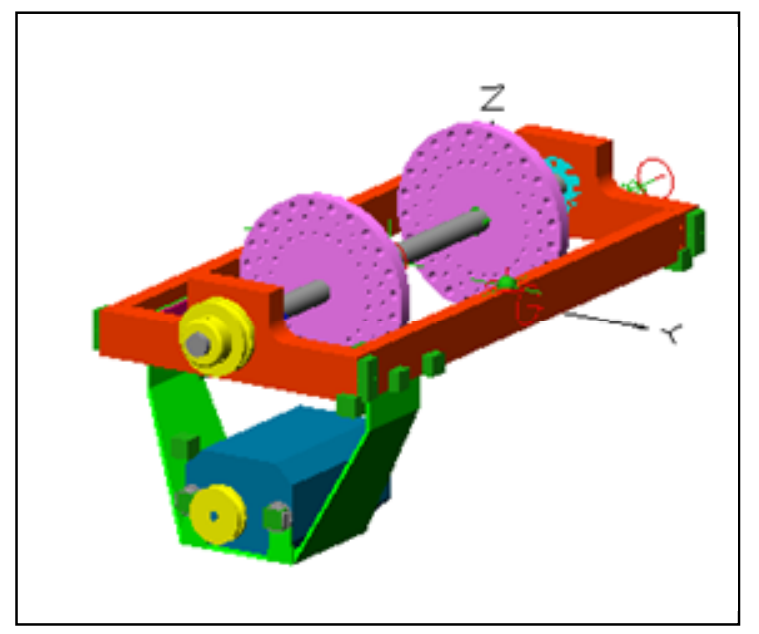

Gambar 11. Pemodelan CAD tanpa massa 
Proses analisis dilakukan dengan cara memasukkan : Dimensi aktual, Massa Jenis tiap komponen, tumpuan (Constraint) dll. Semua parameter tersebut dimasukkan sesuai dengan komponen nyata. Rotor yang dideskripsikan adalah rotor yang ideal, artinya rotor tersebut secara fisik tidak mengalami cacat, tidak mengalami ketidaksilindrisan, kondisi-kondisi ideal seimbang pada saat tidak diberi beban.

\section{Pemodelan Ketakseimbangan Statik}

Pada pemodelan ini digambarkan benda uji dengan menggunakan beban tak balans dengan beda posisi $0^{\circ}$, Parameter kecepatan putar dimasukan yaitu Rotor diputar pada kecepatan $1200 \mathrm{rpm}$ dengan diberi massa tak balans sebesar 20,51 gram pada jarak terluar disk.

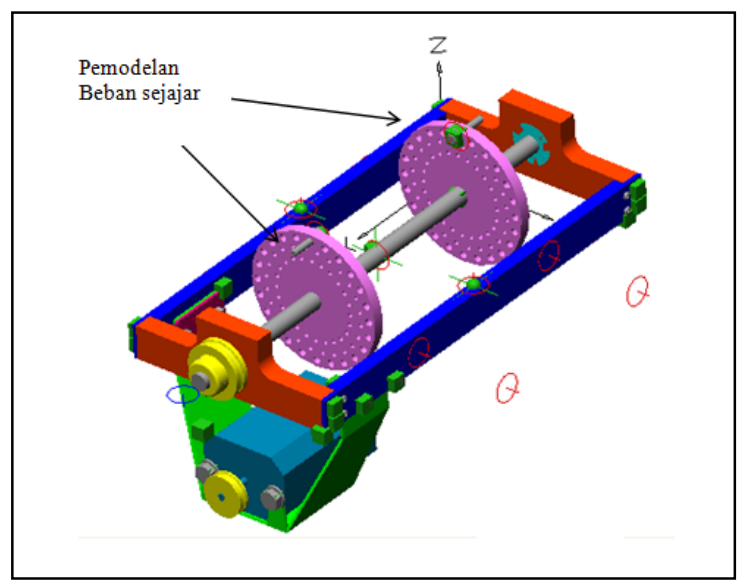

Gambar 12. Pemodelan CAD dengan massa model statik

\section{Pemodelan Dinamik}

Pada pemodelan ini digambarkan benda uji dengan menggunakan beban tak balans dengan beda posisi $180^{\circ}$, Rotor diputar pada kecepatan $1200 \mathrm{rpm}$ dengan diberi massa unbalance sebesar 20,51 gram pada.

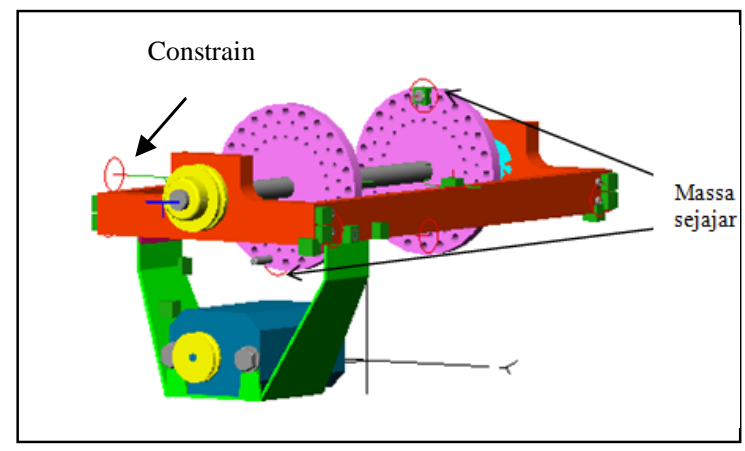

Gambar 13. Pemodelan CAD dengan massa model dinamik
Dengan pemodelan ini pegas \& redaman juga dimodelkan constraint. Harga pegas \& redaman tersebut dimasukan secara langsung pada input data. Pendekatan tersebut dapat ditampilkan pada gambar $12 \& 13$.

Setelah itu dilakukan analisis dengan model rotor yang diputar dengan kecepatan yang diinginkan, kemudian nilai redaman secara bertahap dimasukan kedalam input sampai mendekati hasil eksperimen. Hasil yang diperoleh adalah berupa percepatan pada titik tertentu, sehingga yang dibandingan dengan nilai percepatan (pada posisi penempatan sensor).

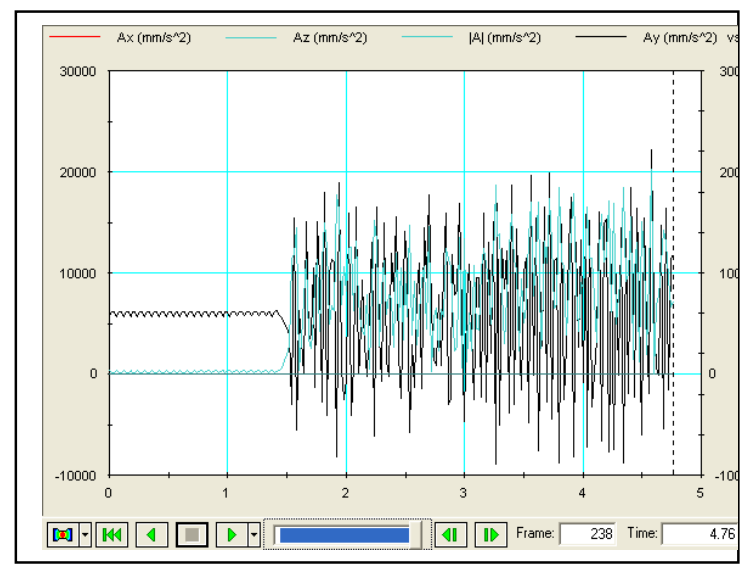

Gambar 14. Hasil Analisis V. NASTRAN 3D 2003 (static unbalance)

Parameter massa bahan, harga kekakuan \& harga redaman memegang peranan yang penting untuk memperoleh hasil yang sesuai. Dengan pendekatan ini menunjukan nilai percepatan terhadap waktu yang di peroleh pada posisi sensor. Yaitu antara $-5 \mathrm{~m} / \mathrm{s}^{2}-25$ $\mathrm{m} / \mathrm{s}^{2}$ pada axis $\mathrm{Y}$.

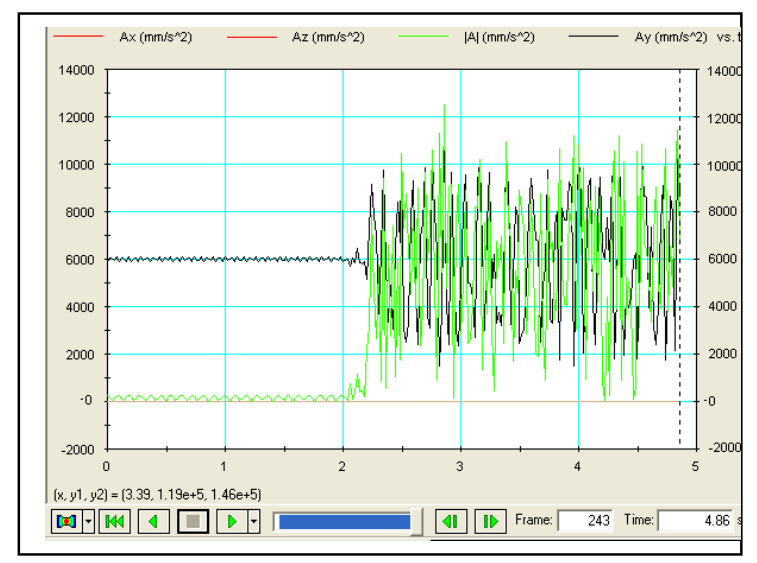

Gambar 15. Hasil Analisis V. NASTRAN 3D 2003 (dynamic unbalance) 
Dengan pendekatan ini menunjukan nilai percepatan terhadap waktu yang diperoleh pada posisi sensor. Yaitu antara $1.8 \mathrm{~m} / \mathrm{s}^{2}-10$ $\mathrm{m} / \mathrm{s}^{2}$ pada axis $\mathrm{Y}$.

\section{VALIDASI DENGAN PENDEKATAN ANALITIK}

Pada pendekatan ini mengacu pada referensi (Thomson, 1993) pendekatannya dengan menggunakan Metode Pseudo-Modal atau Metode Langsung (direct methode) kedua metode tersebut bisa digunakan untuk mendapatkan respon ketakseimbangan massa untuk multi rotor yang sesumbu. Penggunaan persamaan-persamaan mariks serta penerapannya menggunakan bantuan MathLAB. Berikut adalah diagram alir pembuatan program :

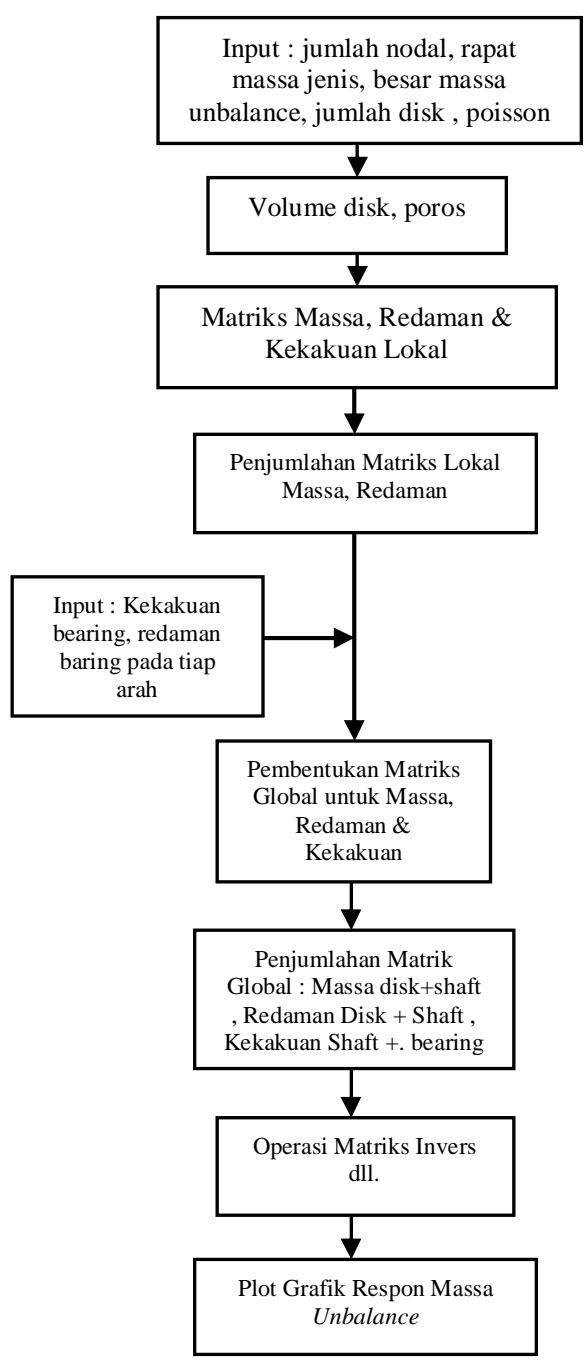

Gambar 16. Flowchart Program Untuk PseudoModal Methode (Msc Nastran, 2005)
Hasil dari ekperimental belum merepresentasikan kekakuan \& redaman yang sesuai dengan data teoritik yang diberikan, dikarenakan spesifikasi bearing yang belum diperoleh. Untuk mengatasi permasalahan tersebut maka dilakukan pendekatan analitik dengan cara memasukan nilai kekakuan pada setiap perhitungan melalui range yang proporsional secara bertahap. Proses yang dilakukan adalah dengan menggunakan beberapa persamaan

Maka berikut ditunjukan hasil-hasil dari pemberian nilai kekakuan dan redaman sampai diperoleh nilai yang sesuai dengan eksperimental. Perhitungan berikut dilakukan berdasarkan sistim perhitungan 1x $1200 \mathrm{rpm}$ tak balans statik. Asumsi yang diberikan dengan batasan sebagai berikut : (a) Nilai yang diubah adalah hanya kekakuannya saja sedangkan nilai redaman diasumsikan tetap (b) Setiap arah kekakuan di anggap sama $\mathrm{Kxx}=\mathrm{Kzz}$ dan $\mathrm{Kxz}=\mathrm{Kzx}=0$. (c) Pembebanan massa unbalance yang sama.

Pada aksis y secara teoritik di berikan nilai jarak (m) untuk membantu dalam melihat perubahan respon karena perubahan kekakuan bearing. Perhitungan-1. Pemberian nilai kekakuan $\mathrm{K}=7 \times 10^{6} \mathrm{~N} / \mathrm{m} \mathrm{C}=4 \times 10^{2} \mathrm{~N} / \mathrm{m} / \mathrm{s}$, menghasilkan sinyal sebagai berikut :

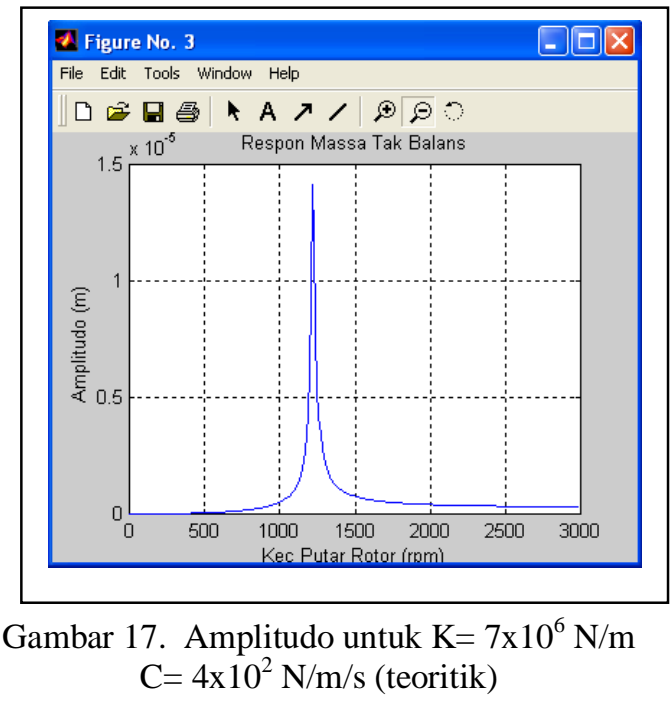

Pada hasil ini belum menunjukan kesamaan amplitude, dengan hasil eksperimental. Amplitudo lebih kecil dari yang hasil eksperimental, ini menunjukan pengaruh kekakuan yang berbeda dari asumsi teoritik. Dimana asumsi kekakuan pada nilai teoritik lebih besar. (untuk nilai axis y adalah hasil- 
konversi nilai percepatan terhadap jarak yang diolah kedalam jarak)

Perhitungan-2. Pemberian nilai kekakuan $\mathrm{K}=$ $6.5 \times 10^{6} \mathrm{~N} / \mathrm{m} \mathrm{C}=4 \times 10^{2} \mathrm{~N} / \mathrm{m} / \mathrm{s}$, menghasilkan sinyal sebagai berikut :

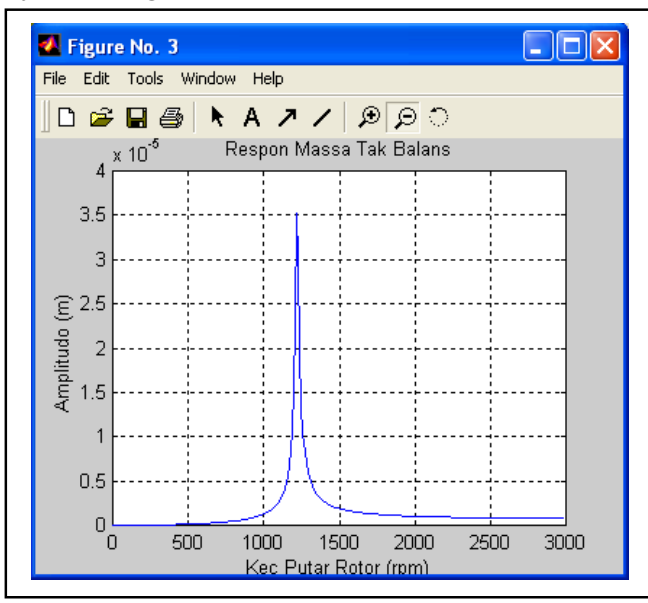

Gambar 18 Amplitudo untuk $\mathrm{K}=6.5 \times 10^{6} \mathrm{~N} / \mathrm{m}$ $\mathrm{C}=4 \times 10^{2} \mathrm{~N} / \mathrm{m} / \mathrm{s}$

Perhitungan-3 . Pemberian nilai kekakuan $\mathrm{K}=$ $5 \times 10^{6} \mathrm{~N} / \mathrm{m} \mathrm{C}=4 \times 10^{2} \mathrm{~N} / \mathrm{m} / \mathrm{s}$, menghasilkan sinyal sebagai berikut :

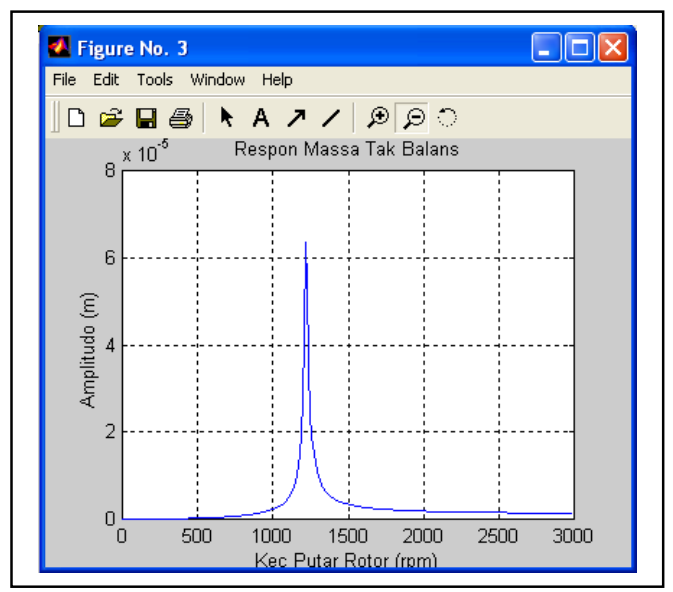

Gambar 19. Amplitudo untuk $\mathrm{K}=5 \times 10^{6} \mathrm{~N} / \mathrm{m}$ $\mathrm{C}=4 \times 10^{2} \mathrm{~N} / \mathrm{m} / \mathrm{s}$

Perhitungan- 4 . Pemberian nilai kekakuan $\mathrm{K}=$ $4,5 \times 10^{6} \mathrm{~N} / \mathrm{m} \mathrm{C}=4 \times 10^{2} \mathrm{~N} / \mathrm{m} / \mathrm{s}$, menghasilkan sinyal sebagai berikut :

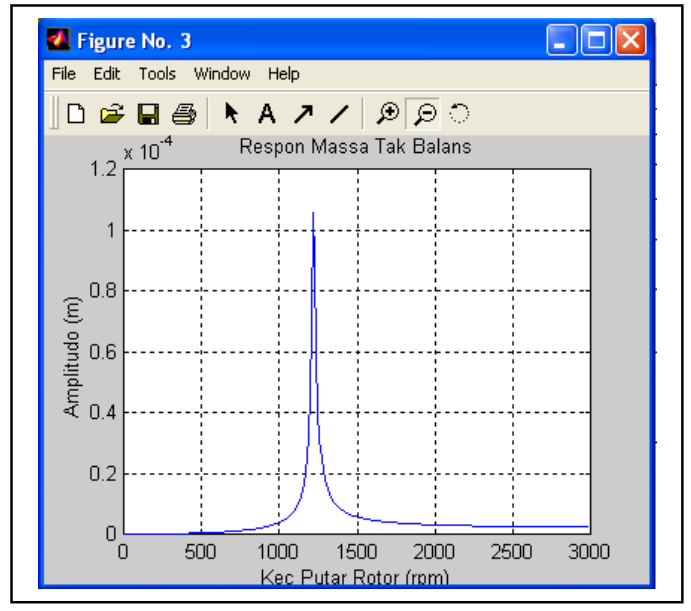

Gambar 20. Amplitudo untuk $\mathrm{K}=4.5 \times 10^{6} \mathrm{~N} / \mathrm{m}$ $\mathrm{C}=4 \times 10^{2} \mathrm{~N} / \mathrm{m} / \mathrm{s}$

Berdasarkan hasil coba-coba yang dilakukan secara bertahap seperti yang digambarkan pada gambar 17 s/d gambar 20, dapat disimpulkan berdasarkan asumsi ini bahwa kekakuan untuk bearing \& adalah : $\mathrm{K}=4.5$ $x 10^{6} \mathrm{~N} / \mathrm{m} \mathrm{C}=4 \times 10^{2} \mathrm{~N} / \mathrm{m} / \mathrm{s}$

Secara analitik dilakukan dengan memberikan beban pengimbang pada bagianbagian posisi yang sudah diberi massa balance. Hasil program yang telah dibuat dituangkan dalam grafik. Hasil yang diperoleh sama seperti yang diperoleh dari proses perhitungan jika tidak diberi massa pengimbang.

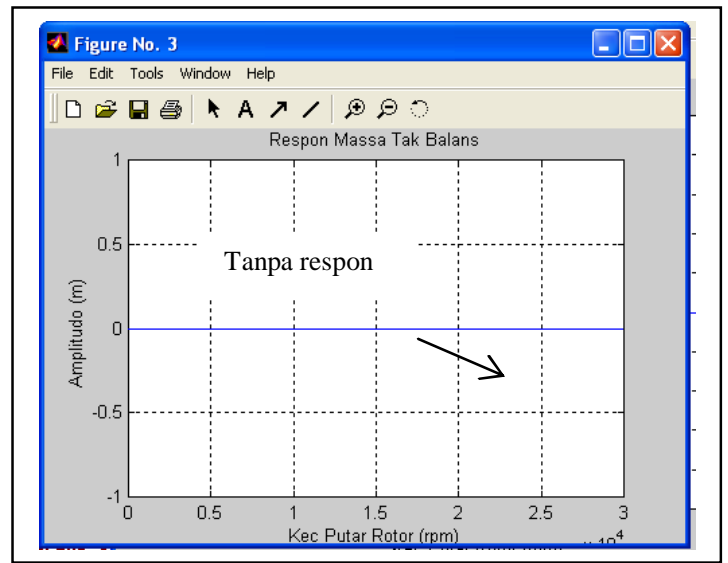

Gambar 21. Grafik hasil pengukuran setelah proses balancing (Secara teoritik)

Bisa dilihat dari grafik diatas diambil kesimpulan bahwa pada untuk penyeimbangan unbalance diperoleh hasil yang ideal, tanpa ada sinyal lain seperti halnya pada hasil eksperimental. 


\section{Proses Filter dengan MathLab}

Filter dilakukan dengan tuijuan menapis beberapa frekuensi yang tidak diperlukan atau bukan merupakan akibat massa tak seimbang. Secara hardware penapisan dapat dilakukan dengan bantuan penapis frekuensi rendah (lowpass filter) yaitu dengan mengunakan kapasitor (10 nF 100V).

Bisa juga filter dilakukan dengan cara software dengan menggunakan Butterworth Lowpass Filter pada Math-LAB. Hasil rancangan filter jenis Butterworth Lowpass Filter (Sinaga, 1999) Program filter/tapisan dengan math-Lab, digambarkan sebagai berikut :
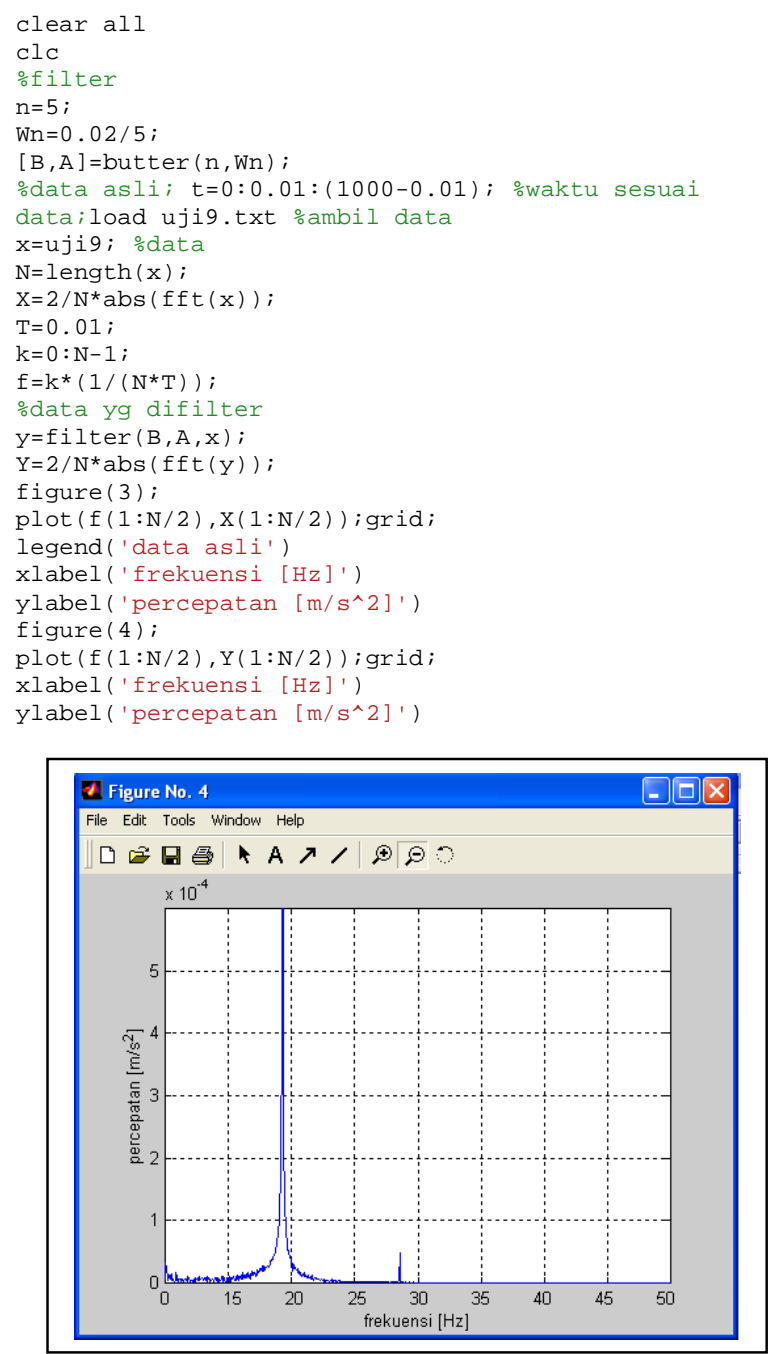

Gambar 22. Grafik hasil Butterworth Lowpass Filter
Penapisan ini juga bisa digunakan pada setiap frekuensi setelah kemunculan puncak akibat massa tak balans, dalam hal ini penapisan frekuensi setelah $20 \mathrm{~Hz}$. Sistim Butterworth Lowpass Filter menggunakan prinsip polynomial, sehingga semakin tinggi orde polinomnya maka akan semakin memberikan kehalusan.

\section{Hasil Balancing}

Tahap berikutnya adalah balancing. dengan menggunakan metode sudut fasa, dilakukan proses balancing dengan prosedur pada persamaan (1) s.d (8) yang yang telah dijelaskan diatas. Kemudian setelah itu dilakukan pengukuran ulang/pengujian ulang dengan data akuisisi diperoleh grafik seperti terlihat dibawah ini

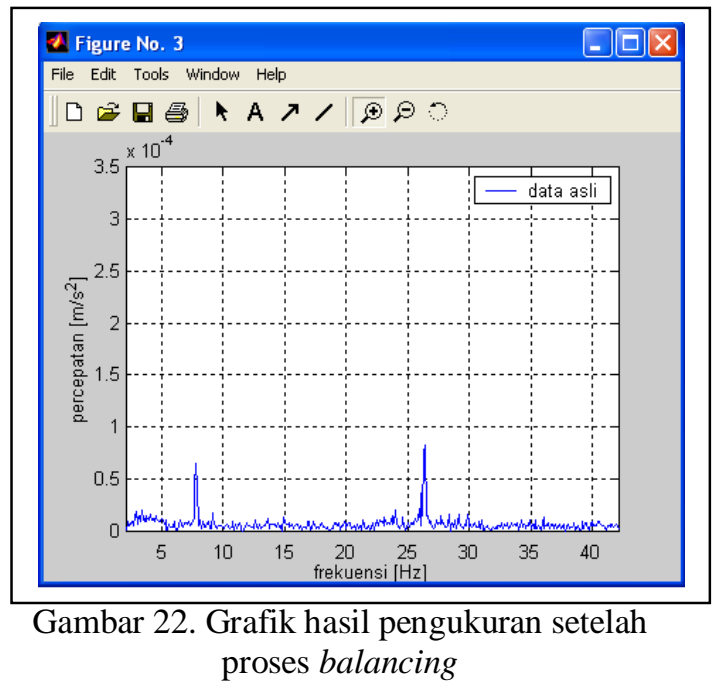

Dari grafik diatas dapat disimpulkan bahwa fluktuasi ada disekitar $1-1.5 \times 10^{-5}$ kondisi ini merupakan kondisi yang paling seimbang yang telah dilakukan untuk proses penyeimbangan, hasil yang diperoleh identik seperti yang dihasilkan pada kondisi tdk diberi beban.

\section{KESIMPULAN \\ Kesimpulan}

Berdasarkan semua yang telah dilakukan pada penelitian ini dapatlah dikemukakan sebagai berikut :

- Dari hasil pengujian menunjukan hasil Penyeimbang dinamik dengan metode sudut-fasa cukup baik, walaupun dari beberapa percobaan, sinyal masih menunjukan noise, akibat getaran bearing dan motor listrik. Sinyal pengganggu dapat dihindari dengan menggunakan isolator 
medan magnet. Selain itu dapat juga dilakukan filter secara hardware (salah satunya dengan menggunakan kapasitor) atau filter secara software.

- Poros-rotor peraga yang dibuat mampu merepresentasikan sinyal akibat massa static-unbalance dan dynamic-unbalance

- Dalam pengoperasian terjadi penurunan putaran/frekuensi uji antara hasil pengukuran dan setting operasi benda (terjadinya sampling). Hal ini disebabkan oleh redaman struktur dan juga faktor beban/slip pada puli motor penggerak.

- Hasil teoritik cukup mendekati hasil yang diperoleh dengan eksperimental, melalui pemberian harga kekakuan \& redaman secara bertahap.

- Penggunaan filter jenis Butterworth akan mengurangi amplitudo sinyal yang difilter, hal ini disebabkan karena filter jenis ini bukan ideal filter tetapi merupakan transisi antara bandpass dan bandstop filter.

- Pada pengukuran ketakseimbangan terjadi penurunan puncak amplitude yang relatif lebih rendah dari pada kondisi statik.

\section{DAFTAR PUSTAKA}

Dianviviyanthi. 2000. Pendeteksian Cacat Tak Balans Pada Sistem Poros Rotor Dengan Teknik Pemodelan Waktu dan Pengenalan Pola. Bandung:Tugas Magister Jurusan Teknik Mesin ITB

Fair. 2001. Pembuatan dan Pengujian Perangkat Lunak Pengakuisisi Data Berbasis LAB VIEW® 4.1 Untuk Mesin Penyeimbang. Bandung:Tugas Sarjana Jurusan Teknik Mesin ITB.
Indrajana, A. 1993. Penyempurnaan Konstruksi dan Pengujian Dinamik Mesin Penyeimbang Mampu Atur Berkapasitas $500 \mathrm{~kg}$. Bandung:Tugas Sarjana Jurusan Teknik Mesin ITB.

Lab Dinamika. 1997. Bahan Kuliah Kursus Singkat Getaran Permesinan Tingkat Lanjut, Diktat Kursus, Bandung : Lab. Dinamika PPAU-IR ITB.

Lalanne, M\&Ferraris, G. 1990. Rotordynamics Prediction in Engineering. John Willey and Sons.

Nasution, A.Z. 1999. Integrasi Perangkat Lunak dan Pengujian Prestasi Mesin Penyeimbang Berkapasitas $100 \mathrm{Kg}$, Bandung : Tugas Sarjana, Jurusan Teknik Mesin ITB.

Sinaga, RM. 1999. Pengembangan Penganalisis Sinyal dinamik 4 Kanal Berbasis Komputer dengan perangkat Lunak LabView. Bandung:Tugas Sarjana Jurusan Teknik Mesin ITB.

TUTORIAL ; MSC Visual NASTRAN Dekstop (2005)

Thomson, WT. 1993. Theory of Vibration with Application, Four Edition. USA:McGrawHill.

Ullman, David G. 2009. The Mechanical Design Process, 4th edition. USA:Mc Graw Hill.

Vance,John M. 1988. Rotordynamic of Turbomachinery. John Willey \& Son. 